\title{
An Attempt at a New Arrangement of Some Japanese Alpine Species of Draba.
}

By

\section{H. Takeda.}

Half a dozen species of Draba are known from the Alpine region of high mountains in Central Japan. Except one species, D. japonica Maxim., all these belong to the Section Leucodraba, and are of comparatively recent discovery. The following species:-D. Sakuraii Makino, D. sinanensis Makino, D. nipponica Makino, and D. ondakensis Makino were published in 1903,* and D. shiroumana in the following year $\dagger$ by the same author. While the last one is quite a distinct species, the others are very similar to each other. The plants are small perennials attaining about $15 \mathrm{~cm}$. high or less even at the period of fruit; the rosette leaves oblong or oblanceolate, dentate or entire, cauline ones elliptical or ovate, more or less coarsely dentate; flowers small, white; silicles oblong with short style, glabrous, generally more or less twisted or plane; seeds elliptical with tail-like appendage at the chalazal end. This final character is, I think, quite a rare thing among Drabas and presents a peculiar feature showing certain natural relationship. The only distinction between $D$. Sakuraii and $D$. sinanensis is the hair on the pedicel, which is present in the former and absent in the latter. Such a distinction is really not of specific value, and moreover this character is not constant, so that these two should be considered as one and the same species. The third one, D. nipponica, seems to be rather different from the above mentioned, being less hairy and having the stem more gracile, the leaf more deeply cut. On the whole,

* Tôkyô Botanical Magazine, vol., xvii., p. 40-42.

$\dagger$ id. op. vol. xviii. p. 75 . 
the plant is, however, not to be regarded as a separate and distinct species, for it possesses the same general character. The fourth plant, $D$. ondakensis, is, so far as I can make out from the original description, characterised by having leaves incano-pubescent, radical ones oblanceolate or narrowly oblanceolate, 2-4-dentate, cauline ones oblanceolate to oblong, dentate or entire, stem pubescent, rachis of the raceme pubescent, pedicels puberulent or glabrate, silicle broadly linear or linear, straight, glabrous with short style, seeds oblong-elliptical, manifestly tailed. The peculiarity of this one is the straight pod, which is more or less twisted in the other forms. Although it is to a certain extent remarkable, still this character does not afford any specific value, just as in $D$. borealis.*

Meanwhile several specimens from various localities have been placed in my hands, which have a similar appearance and the same general character as the known forms. An
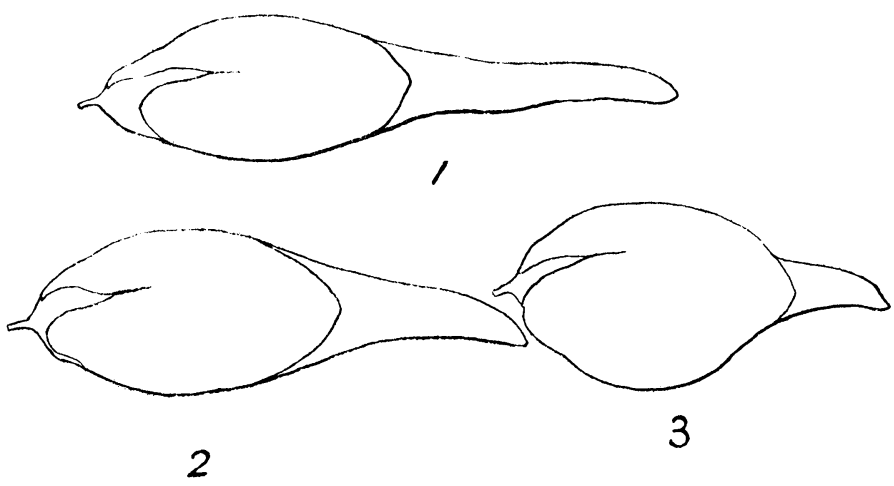

1. Draba Sakuraii, a genuina.

2. $" \quad, \quad \beta$ nipponica.

3. $, \quad, \quad \gamma$ rigida.

All magnified fifteen times.

arrangement of these forms under one species may possibly be made according to the hairiness of the plant and the form of the leaf. The relationship and difference between each form

* With regard to this species c.f. my paper 'Beiträge zur Kenntnis der Flora von Hokkaidô,' no-48, published in the 'Tôkyô Botanical Magazine, 1910. 
is also well illustrated by the length of the tail-like appendage of the seed. The height at the plant and size of the leaf does not exhibit much constancy, since the plant varies according to the circumstances of its habitat. The following arrangement is principally based on the seed-character, and will, I hope, be a more natural one than treating them as distinct species. I have to add here that I have not been able to examine the seed of the form 'ondakensis,' so that I cannot place it in its proper position, but satisfy myself for the present by placing it near var. rigidula as the fourth variety.

Draba Sakuraii Makino, emend.

$\alpha$. genuina TAKEDA.

Syn. Draba Sakuraii Makıno, in Tôkyô Bot. Mag. xvii. (1903), p. 40.

Syn. Draba sinanensis Makino, 1. c.

Caule pubescente, pedicellis glabris vel parce pubescentibus. Foliis pubescentibus, radicalibus oblongis oblanceolato-spathulatisve, basin versus plus minus attenuatis, apicem versus 2-6-dentatis, integrisve, caulinis ellipticis ovatisve, plus minus argute dentatis. Semina appendicileus æquilonga vel parum breviora.

Hab. in monte Togakushi (S. KAWADA et H. TAKFDA! 19 VII. 1904).

ß. nipponica TAKEDA.

Caule sæpe humiliore, glabrescente vel inferne pubescente. Foliis radicalibus tenuiter pubescentibus, anguste oblanceolatis linearispathulatisve interdum linearibus, basin versus attenuatis, apicem versus argute 2-4. vel 6-dentatis integrisve, caulinis glabrescentibus, oblongis oblongo-lanceolatisve raro ovatis plus minus pectinato-dentatis. Seminis appendices semina sua $\frac{1}{2}-\frac{3}{5}$ vel subaequilongae.

Forma a. typica TAKeda.

Syn. Draba nipponica Makino, 1. c. p. 41.

Caule gracile, glabrescente. Foliis tenuis, radicalibus linearispathulatis, caulinis saepe glabratis, oblongis, profunde et laxe pectinatis. Siliquis saepe plus minus contortis. Appendicibus seminis semina sua $\frac{1}{2}$ vel subaequilongis. 
Hab. in montibus Yatsugatake (S. Kawada et H. TAKeda! 27. VII. 1903 ; H. TAKeda！9. VIII. 1905 ; M. Ishikawa！ 31. VII. 1904; M. Tsujimoto! 31. VIII. 1908).

Forma b. intermedia TAKEDA.

Caule tenue, inferne parce pubescente. Foliis tenuibus parce pubescentibus glabratisve, radicalibus oblanceolato-spathulatis, caulinis ovatis elliptico-ovatisve, argute et profundiusculo dentatis. Appendicibus semina sua $\frac{1}{2}$ aequilongis.

Hab. in monte Komagatake, tractus Kiso (S. KAwADA! 4. VIII. 1906).

Forma c. angustifolia TAKedA.

Caule gracile, inferne saepius pubescente. Foliis tenuibus, angustioribus, radicalibus nonnunquam linearibus edentatisque, pubescentibus, caulinis multo sed interdum leviter pectinatodentatis, saepissime glabrescentibus. Siliquis saepius contortis; appendicibus semina sua $\frac{1}{5}-\frac{3}{5}$ aequilongis.

Hab, in montibus Hôwôzan (M. Tsujimoto ! 13. VIII. 1906 ; H. TAKEda! 26. VIII. 1906 ; M. Kawada! VIII. 1908); in monte Senjôdake (M. Kurushima! IX. 1909).

\section{$\gamma$. rigidula TAKEDA.}

Caule crassiusculo, rigidulo, strictulo, glabrescente, rarius inferne parce pubescente. Foliis crassiusculis, radicalibus densius pubescentibus, oblanceolatis, paucidentatis, integrisve, caulinis oblongis, leviter pauci - subpectinato-dentatis. Siliquis planis; appendicibus parvis, semina sua fere $\frac{1}{3}$ aequilongis.

Hab. in monte Komagatake, prov. Kai (H. TAKEDA! 29. VIII, 1906).

? $\delta$. ondakensis (Makino) TAKEDA.

Syn. Draba ondakensis Makino, 1.c. p. 42.

Caule pubescente. Foliis incanopubescentibus, radicalibus oblanceolatis vel anguste oblanceolatis, 2-4-dentatis, caulinis oblanceolatis vel oblongis, dentatis interdum integris. Siliquis late linearibus vel linearibus; semina oblongo-elliptica,-ex Makino.

Hab. in monte Ontake, tractus Kiso (sec. Makino).

As the botanical exploration of Japan proceeds, we may obtain other forms of this species, for which I hope room will be found if the seed-character is properly examined.

Herbarium, Royal Botanic Gardens, Kew.

July 1911. 